\title{
Antibacterial Activity of Beluntas (Pluchea indica L.) Leaves Extract using Different Extraction Methods
}

\author{
Uji Aktivitas Antibakteri Ekstrak Daun Beluntas (Pluchea indica L.) Menggunakan Metode \\ Ekstraksi yang Berbeda
}
Kinanti Ayu Puji Lestari*, Putri Priliawati Pranoto, Sofiyah, Majidah Musyirah, Faizatin Isnaini Pratiwi
D3 Pharmacy Study Program, Akademi Farmasi Surabaya

\section{Article History \\ Received : 14 June 2020 Approved : 16 August 2020 \\ Published : 30 September 2020}

Keywords: Antibacterial activity, beluntas leaves, soxhletation method

Kata Kunci: Aktivitas antibakteri, daun beluntas, metode soxhlet

\begin{abstract}
Escherichia coli and Bacillus subtilis are bacteria that cause disease in the digestive tract. Pluchea indica L. had the pharmacological activity of antiseptic power against bacteria that cause digestive tract infections because of contained antibacterial compounds. The study on the comparison of extraction methods will enable the public to choose a better extraction method to use as an antibacterial agent. This study aimed to identify the content of antibacterial compounds in Pluche indica L. and to determine the antibacterial ability of Pluche indica L. extract using maceration, percolation, and soxhletation methods. The results showed that Pluchea indica L. contains flavonoids, alkaloids, saponins, and tannins. The highest diameter inhibition of Escherichia coli and Bacillus subtilis was obtained from Pluchea indica L. leaves extract extracted by using the Soxhletation method.
\end{abstract}

\begin{abstract}
Abstrak
Escherichia coli dan Bacillus subtilis merupakan bakteri penyebab penyakit pada saluran pencernaan. Pluchea indica L. memiliki aktivitas farmakologi daya antiseptik terhadap bakteri penyebab infeksi saluran pencernaan karena mengandung senyawa antibakteri. Kajian tentang perbandingan metode ekstraksi akan memungkinkan masyarakat untuk memilih metode ekstraksi yang lebih baik untuk digunakan sebagai agen antibakteri. Penelitian ini bertujuan untuk mengidentifikasi kandungan senyawa antibakteri dalam Pluche indica L. dan untuk mengetahui kemampuan antibakteri ekstrak Pluche indica L. menggunakan metode maserasi, perkolasi, dan soxhlet. Berdasarkan hasil penelitian menunjukkan bahwa Pluchea indica L. mengandung flavonoid, alkaloid, saponin, dan tanin. Hambatan diameter tertinggi Escherichia coli dan Bacillus subtilis diperoleh dari ekstrak daun Pluchea indica L. dengan metode Soxlet.
\end{abstract}

How to cite: Lestari, K.A.P., Pranoto, P.P., Sofiyah, Musyirah, M., \& Pratiwi, F.I. (2020). Antibacterial Activity of Beluntas Extract (Pluchea indica L.) using a Different Extraction Method. Jurnal Riset Biologi dan Aplikasinya, 2(2), 49-54. 


\section{INTRODUCTION}

Pathogenic bacteria in the gastrointestinal tract are a group of bacteria that can cause gastrointestinal disease (Radji \& Maksum, 2011). Digestive tract disease which is diarrhea, can be caused by bacteria and parasites (Zein, 2004). The bacteria that cause diarrhea are Escherichia coli. Besides, Bacillus subtilis also has the ability as a pathogen in the digestive tract. Most of the Escherichia coli and Bacillus subtilis are in the digestive tract as the normal flora (Bettelheim, 2000). These bacteria become pathogenic and caused diarrhea when their numbers increase in the digestive tract (Jawetz, 2005). Various medicinal plants have been believed to have properties to treat certain diseases and as an alternative treatment for certain diseases (Agoes, 2010). One of the plants containing medicinal compounds is Pluchea indica L. (Nurhalimah et al., 2015). Pluchea indica L. also has a pharmacological activity of antiseptic power against bacteria that cause digestive tract infections (Ismi et al, 2010). Pluchea indica L. leaves contain alkaloids, tannins, essential oils, sodium, potassium, aluminum, calcium, magnesium, phosphorus, and flavonoids (Dalimartha, 1999), and these compounds are believed to be antibacterial compounds.

Most of the research on Pluchea indica L. leaves focuses more on antibacterial testing, such as research on the antibacterial testing of Pluchea indica L. leaves against Propionibacterium acne (Hafsari et al, 2015; Suru et al., 2019), Staphylococcus aureus, Bacillus subtilis, and Pseudomonas aeruginosa (Manu, 2013), Mycobacterium tuberculosis (Amilah \& Ajiningrum, 2015), and Escherichia coli (Mulyadi et al., 2016). Research about the use of the extraction method used to obtain extracts is still minimal, even though the type of extraction method can affect the content and biological activity of chemical compounds that are suspected to be antibacterial. Besides, a study on the comparison of extraction methods will allow the public to choose an extraction method that allows better extraction for use as an antibacterial agent. This study aims to determine the antibacterial ability of beluntas leaves extract (Pluchea indica L.) in inhibiting the growth of Escherichia coli and Bacillus subtilis using three different extraction techniques, maceration, percolation, and soxhletation.

\section{MATERIALS AND METHODS}

\section{Reagen and chemical compound}

Reagen and chemical compound were collected from Department of Chemistry, Universitas Negeri Surabaya which are Reagen Mayer, reagen Dragendorf, dan reagen Wagner, $\mathrm{HCl}, \mathrm{Mg}$ powder and $\mathrm{FeCl}_{3}$.

\section{Bakteria and sample}

The bacteria used in this study were Bacillus subtilis collected from ULP (Research Service Unit) Airlangga University Surabaya, and Escherichia coli ATCC 25922 collected from BBLK (Central Health Laboratory) Surabaya. The bacteria then recultured in Nutrient Agar media (Merck, Jerman) and stored in an incubator at the temperature of $30^{\circ} \mathrm{C}$. Pluchea indica L. leaves were collected from MMI (Materia Medika Indonesia).

\section{Extraction preparation}

The extraction methods used in this research were maceration, percolation and soxhletation methods.

1. Maceration method.

Dried Pluchea indica L. leaves powder (100 g) was extracted using methanol $(1000 \mathrm{~mL})$ solvent in a ratio of $1: 10$ for 10 days at $25-30^{\circ} \mathrm{C}$ and then filtered. The extraction was remaceration twice with the new solvent in same volume. The extract was filtered using Whatman filter paper no.1.

\section{Percolation method}

Dried Pluchea indica L. leaves powder (100 g) was soaked using methanol (1000 $\mathrm{mL}$ ) solvent in a ratio of $1: 10$ in a percolator for 24 hours at a temperature of $25-30^{\circ} \mathrm{C}$. Extraction was repeated twice with the new solvent and the same volume.

\section{Soxhletasion method}

Dried beluntas leaves powder (100 g) was soaked using methanol $(1000 \mathrm{~mL})$ solvent in a ratio of 1:10 using the Soxhlet method for 10 hours.

The entire filtrate from each extraction method was evaporated using a rotary evaporator under pressure at a temperature of $40{ }^{\circ} \mathrm{C}$. The filtrate was then diluted with sterile aquadest to make a concentration of $1500 \mathrm{ppm}, 2000 \mathrm{ppm}$ and 2500 ppm. Aquadest were also as a control.

\section{Qualitative phytochemical assay}

A qualitative phytochemical test was carried out to determine the presence of compounds that play a role in the process of inhibiting bacterial 
growth. These compounds are limited to include flavonoids, alkaloids, saponins and tannins.

1. Flavonoid assay

Pluchea indica L. leaves filtrate $(1 \mathrm{~mL})$ was added with $2 \mathrm{~N} \mathrm{HCl}(2 \mathrm{~mL})$ and $\mathrm{mg}$ powder $(1 \mathrm{mg})$ then shaken homogeneously. The sample was stated as positive for containing flavonoid compounds if there was appearence a yellow or red orange color in the tube.

\section{Alkaloid assay}

Pluchea indica L. leaves filtrate $(1 \mathrm{~mL})$ was put in 3 different test tubes then added with $2 \mathrm{~N} \mathrm{HCl} \mathrm{(2}$ $\mathrm{mL})$. Dragendroff reagent was dropped on tube 1 , Mayer's reagent in tube 2 , and Wagner reagent in tube 3 three drop each test tube then shaken homogeneously. The sample is said to be positive for containing alkaloid compounds if there is appearence an orange red precipitate in tube 1 , greenish white in tube 2 and brownish black in tube 3.

\section{Saponin assay}

Pluchea indica L. leaves filtrate $(1 \mathrm{~mL})$ was added with hot aquadest $(2 \mathrm{~mL})$ then cooled. Then shake vigorously for 10 seconds. The sample is said to be positive for containing saponin compounds if a constant foam is formed for 10 minutes in the test tube.

\section{Tannin assay}

Pluchea indica L. ( $1 \mathrm{~mL}$ ) added 2 drops of $\mathrm{FeCl}_{3}$ then shaken homogeneously. The sample is said to be positive for containing tannin compounds if there is appearence a blackish green color in the tube.

\section{Bacterial suspension}

Nutrient Broth (Merck, Jerman) (3,6 g) dissolved in aquadest $(180 \mathrm{~mL})$ then sterilized using autoclave under a pressure of $1 \mathrm{~atm}$, temperature $121{ }^{\circ} \mathrm{C}$ for 30 minutes. Each bacteria were inoculated in sterile Nutrient Broth aseptically and incubated in an incubator at $30{ }^{\circ} \mathrm{C}$ for 24 hours.

\section{Antibacterian activity test}

Antibacterial activity test was in vitro using the well method with four replications. The bacterial suspension $(1 \mathrm{~mL})$ was put in a sterile petri dish and added with sterile Nutrient Agar media (15 mL) then homogenized (pour plate method). Make a well hole using the well tool no.6 aseptically. Pluchea indica L. leaves extract with each concentration $(30 \mu \mathrm{L})$ was inserted into the hole that was made and then incubated in an incubator at $30^{\circ} \mathrm{C}$ for 24 hours.

\section{RESULTS AND DISCUSSION}

\section{Qualitative phytochemical assay}

The phytochemical content that wanted to observed were flavonoids, alkaloids, saponins and tannins. It is known that the Pluchea indica L. leaves extract using the maceration, percolation and soxhletation method on the flavonoid test tube appeared a yellow color so that it showed positive results containing flavonoids (Table 1). In the alkaloid test, there was an orange red on the Mayer tube, greenish white on the Dragendorf tube and brownish black on the Wagner tube, so that it showed positive results containing alkaloids. In the saponin test, a constant foam was formed for 10 minutes, so it showed a positive result containing saponins and the tannin test a blackish green color was formed, so that it showed a positive result containing tannins.

Phytochemical qualitative testing is carried out to determine the presence of antibacterial compound contained in Pluchea indica L. leaves. These compounds included flavonoids, alkaloids, saponins and tannins. The results of the phytochemical screening of the Pluchea indica L. leaves extract (Table 1) showed that flavonoids, alkaloids, saponins and tannins were found in the extracts that were extracted by three different methods, which were maceration, percolation and soxhletation. This is the same as the results of previous studies (Khotimah, 2016; Widyawati et al, 2011) which stated that beluntas leaves extract positively contained flavonoids, alkaloids, saponins and tannins.

Table 1. Qualitative Phytochemical Assay Pluchea indica L. Leaves

\begin{tabular}{llccc}
\hline \multirow{2}{*}{ No. } & \multirow{2}{*}{ Compound } & \multicolumn{3}{c}{ Extraction Method } \\
\cline { 3 - 5 } & & Maserasion & Perkolasion & Soxhletasion \\
\hline 1. & Flavonoid & + & + & + \\
2. & Alkaloid & + & + & + \\
3. & Saponin & + & + & + \\
4. & Tannin & + & + & + \\
\hline
\end{tabular}

Note: $+=$ positif for the test compound; $-=$ negative for the test compound 
Phytochemical qualitative testing was carried out to determine the presence of antibacterial compound contained in Pluchea indica L. leaves. These compounds included flavonoids, alkaloids, saponins and tannins. The results of the phytochemical screening of the Pluchea indica L. leaves extract (Table 1) showed that flavonoids, alkaloids, saponins and tannins were found in the extracts that were extracted by three different methods, which were maceration, percolation and soxhletation. This is the same as the results of previous studies (Khotimah, 2016; Widyawati et al., 2011) which stated that beluntas leaves extract positively contained flavonoids, alkaloids, saponins and tannins.

\section{Antibacterial activity test}

The aims of this research were to determine the antibacterial ability of Pluchea indica L. leaves extract in inhibiting the growth of Escherichia coli and Bacillus subtilis bacteria. The results of the antibacterial activity test data are presented in Table 2 .

This test aims to determine the ability of Pluchea indica L. extract to inhibited the growth of Escherichia coli and Bacillus subtilis bacteria. Based on the interpretation of the test results (Table 2), it is known that the inhibition response of the Escherichia coli and Bacillus subtilis bacteria carried out by the Pluchea indica L. extracts, both extracted using maceration, percolation and soxhletation methods, is in the moderate inhibition category (Pan et al., 2009). However, the mean results show that each has a different value. Beluntas leaves extract with a concentration of $2500 \mathrm{ppm}$ with the Soxhletation method was known to be able to form the largest inhibition zone in Escherichia coli and Bacillus subtilis. This result caused by the extraction method, the solvent used, the well test method and the antibacterial compounds, which affect the bacterial inhibition mechanism.

The maceration and percolation methods were chosen because they are cold extraction methods or without heating, so they can prevent damage to chemical components that are not resistant to heating (Syukur et al., 2012). The purpose of maceration is also to get the chemical components in the sample, where the solvent will penetrate the cell wall and enter the cell cavity containing the active compound. However, the mean results of the inhibition zone diameter of the extracts obtained by the percolation and maceration methods were not higher than the extracts obtained by the Soxhletation method. This can be because the extraction process carried out in the Soxhletation method is more effective so that the results obtained are better and the solvent used is relatively small. In addition, the extraction process carried out by the soxhletation method was able to produce high rendemen and high total phenolic (Puspitasari \& Proyogo, 2017) including flavonoids, alkaloids, saponins and tannins which affected the diameter of the inhibition zone of each bacteria.

This study used methanol as a solvent because it was the polar compound, so it is able to dissolve polar compounds (tannins, alkaloids, flavonoids, saponins). This statement is in accordance with previous research (Thompson, 1985) which states that methanol can attract alkaloids, flavonoids and saponins from plants. Methanol was also chosen because the flavonoid content in Pluchea indica L. is a polar compound so it must be dissolved with a polar type solvent (Koirewoa et al., 2012). Methanol can affect the effectiveness of antibacterial substances so that it can inhibit the growth of the tested bacteria.

The test method used is the well method. This method was chosen because in the process, bacterial cells were not only present on the surface of the medium but also inside to the bottom of the agar medium (Endang \& Maimunah, 2018). This is in accordance with the types of tested bacteria (Escherichia coli and Bacillus subtilis) which are facultative anaerobes whose life is scattered from the surface to the inside of the media.

Table 2. Diameter of Inhibitory Zone

\begin{tabular}{ccccc}
\hline Bakteri & $\begin{array}{c}\text { Konsentrasion } \\
(\mathrm{ppm})\end{array}$ & Maserasion & $\begin{array}{c}\text { Diameter of Inhibitory Zone }(\mathrm{mm}) \\
\text { Perkolasion }\end{array}$ & Soxhletasion \\
\hline Eschericia coli & Kontrol & 0 & 0 & 0 \\
& 1500 & 4.3 & 3.9 & 4.7 \\
& 2000 & 4.7 & 4.2 & 5.1 \\
Bacillus subtilis & 2500 & 5.4 & 4.9 & 5.8 \\
& Kontrol & 0 & 0 & 0 \\
& 1500 & 3.8 & 3.4 & 4.9 \\
\end{tabular}


In the well method, the pit is filled with a concentration of Pluchea indica L. extract to determine its antibacterial properties. The well method can produce a clearer diameter of the inhibition zone than the disc disk method (Prayoga, 2013). This is because the well method occurs better osmolarity than the disk method, because each hole is filled with extract concentrations. The well method allows the osmolarity process to occur more thoroughly and more homogeneously and the resulting extract concentration is higher and stronger to inhibit bacterial growth.

Factors that influence the activity of antibacterial include the amount of antibacterial substances contained in Pluchea indica L., antibacterial compounds in Pluchea indica L. extracts such as flavonoids, alkaloids, saponins and tannins. The mechanism of antibacterial action is saponins which interfere with cell wall permeability resulting in the release of important components, namely proteins, nucleic acids and others (Ismi, 2010). Tannin compounds can shrink cell walls so that they can interfere with the permeability of the cell itself, flavonoids can cause damage to the permeability of bacterial cell walls (Kurniawati, 2001). Alkaloids have antibacterial activity by disrupting the components of peptidoglycan in bacterial cells, so that the cell wall layer is not formed intact and causes cell death (Robinson, 1991). These results indicate that natural ingredients such as Pluchea indica L. have a fairly good ability to be applied as natural antibacterial agents (Paz et al., 2017).

\section{CONCLUSION}

Pluchea indica L. extract that obtained from maceration, percolation and soxhletation extraction contained flavonoids, alkaloids, saponins and tannins. In addition, the extracts from the three extraction methods have antibacterial ability to inhibit Escherichia coli and Bacillus subtilis which are included in the moderate inhibition category. The highest diameter was obtained from Pluchea indica L. leaves extract using the Soxhletation method.

\section{REFERENCES}

Agoes, A., (2010). Tanaman Obat Indonesia. Jakarta: Salemba Medika.

Bettelheim, K. A. (2000). Role of non-0157 VTEC. Journal of Applied Microbiology Symposium Supplement, 88(S1), $38 \mathrm{~S}-50 \mathrm{~S}$.

https://doi.org/https://sfamjournals.onlinelibrary.wi ley.com/doi/abs/10.1111/j.13652672.2000.tb05331.x.
Dalimartha, S. (1999). Atlas Tumbuhan Obat Indonesia. Jilid I. Jakarta: Trubus Agriwidya.

Endang \& Maimunah. (2018). Uji Efektivitas Air Buah Jeruk Nipis (Citrus aurantifolia) dalam Menghambat Candida albicans (Studi di STIkes ICMe Jombang). Karya Tulis Ilmiah. http://repo.stikesicmejbg.ac.id/1477/2/151310011_Endang\%20Maimunah _\%20KTI\%2OPDF.pdf.

Hafsari, A.R., Cahyanto, T., Sujarwo, T (2015). Uji Aktivitas Antibakteri Daun Beluntas (Pluchea indica (L.) LESS. ) terhadap Propionibacterium acnes Penyebab Jerawat Anggita. Journal Istek, IX(1), 142-161. https://journal.uinsgd.ac.id/index.php/istek/article/ view/174/191

Ismi, R., Ratnawati, D.M. and Yudi, R. (2010). Uji Aktifitas Antibakteri Fraksi Aktif Ekstrak Etanolik Daun Beluntas (Pluchea indica L.) dengan Metode Maserasi dan Soxhletasi terhadap Salmonella typhi atcc 13311 Secara Dilusi. Biomedika, 1(2). http:/ / portalgaruda.org/?ref=browse\&mod=viewartic le\&article $=152949$.

Jawetz, E. (1995). Mikrobiologi Kedokteran. Terjemahan Edi Nugroho dan Maulany dari Medical Microbiology (1995). Jakarta : EGC.

Khotimah, K.(2016) Skrining fitokimia dan identifikasi metabolit sekunder senyawa karpain pada ekstrak metanol daun Carica Pubescens Lenne E K. Koch dengan LC/MS (Liquid Chromatograph-tandem Mass Spectrometry). Undergraduate thesis, Universitas Islam Negeri Maulana Malik Ibrahim.

Koirewoa, Y. A., Fatimawali, \& Wiyono, W. I. (2012). Isolasi dan Identifikasi Senyawa Flavonoid Dalam Daun Beluntas (Pluchea indica L.). Pharmacon, 1(1), 47-52. https://doi.org/https://doi.org/10.35799/pha.1.2012 .445 .

Kurniawati, M. (2001). Uji Aktivitas Antibakteri Fraksi Daun Sirsak (Anonna murrcata) terhadap Staphylococcus aureus dan Escherichia coli serta Profil Kromatografi Lapis Tipusnya. Skripsi Fakultas Farmasi Gadjah Mada, Yogyakarta.

Manu, R. R. S. (2013). Aktivitas Antibakteri Ekstrak Etanol Daun Beluntas (Pluchea Indica L.) terhadap Staphylococcus Aureus, Bacillus Subtilis dan Pseudomonas aeruginosa. Calyptra: Jurnal Ilmiah Mahasiswa Universitas Surabaya, 2(1), 1-10. http://www.journal.ubaya.ac.id/index.php/jimus/arti cle/view/162/139

Mulyadi, A. F., Pulungan, H., \& Qayyum, N. (2016). Pembuatan Edible Film Maizena dan Uji Aktifitas Antibakteri (Kajian Konsentrasi Gliserol dan Ekstrak Daun Beluntas (Pluchea Indica L.) Producing of Cornstarch Edible film and Antibacterial Activity Test (The Study of Glycerol Concentration and Beluntas L. Industria: Jurnal Teknologi Dan Manajemen Agroindustri, 5(3), 149-158. https://doi.org/https://doi.org/10.21776/ub.industri a.2016.005.03.5

Nurhalimah, H., Wijayanti, N., \& Widyaningsih, T. D. (2015). Efek Antidiare Ekstrak Daun Beluntas pada Mencit. Jurnal Pangan dan Agroindustri, 3(3), 10831094.

https://jpa.ub.ac.id/index.php/jpa/article/view/231.

Pan, X., Chen, F., Wu, T., Tang, H., \& Zhao, Z. (2009). The acid, bile tolerance and antimicrobial property of Lactobacillus acidophilus NIT. Food Control, 20(6), $598-602$. https://doi.org/10.1016/j.foodcont.2008.08.019.

Paz, J.E.W., Contreras, C.R., Munguia, A.R., Aguilar, C.R., Inungaray, M.L.C. (2017). Phenolic content and 
54 | Lestari et al. Antibacterial Activity of Beluntas Extract (Pluchea indica L.)

antibacterial activity of extracts of Hamelia patensobtained by different extraction methods. Braz $J$ Microbiol. 49(3), 656-661.

Puspitasari, S. A., \& Proyogo, L. S. (2017). Kadar Fenolik Total Ekstrak Etanol Daun Kersen (Muntingia calabura). Jurnal Ilmiah Cendekia Eksakta, 2(1), 1-8. https://doi.org/Perbandingan Metode Ekstraksi Maserasi Dan Sokletasi Terhadap Kadar Fenolik Total Ekstrak Etanol Daun Kersen (Muntingia calabura).

Prayoga, E. (2013). Perbandingan Efek Ektrak Daun Sirih Hijau (Piper betle L) Dengan Metode Difusi Disk dan Sumuran Terhadap Bakteri Staphylococcus aureu. Tesis. 1-3. Universitas Islam Negeri Syarif Hidayatullah Jakarta.

Syukur,R., Alam, G., Mufidah., \& Rahim, R. T. (2011). Aktivitas Antiradikal Bebas Beberapa Ekstrak Tanaman Familia Fabaceae Radical. Kesehatan, 1(1), 61-67.

http://pasca.unhas.ac.id/jurnal/files/e72a6e54ecc12a 1c6d06853e9e5cd778.pdf.

Radji and Maksum., (2011). Buku Ajar Mikrobiologi Panduan Mahasiswa Farmasi \& Kedokteran. Jakarta: Kedokteran ECG.54

Robinson, T. 1991. Kandungan Organik Tumbuhan Tingkat Tinggi. Diterjemahkan oleh Prof. Dr. Kosasih Padmawinata. Bandung: Penerbit ITB.

Amilah, S \& Ajiningrum, P.S. (2015). Uji Efektivitas Daya Hambat Sari Daun Pegagan (Centella asiatica) dan
Daun Beluntas (Pluchea indica Less) Terhadap Pertumbuhan Mycobacterium tuberculosis. Stigma Journal of Science, 8(2), 6-11. https://doi.org/https://doi.org/10.36456/stigma.vol 8.no02.a253

Suru, E., Yamlean, P. V. Y., \& Lolo, W. A. (2019). Formulasi dan Uji Efektivitas Krim Antibakteri Ekstrak Etanol Daun Beluntas (Pluchea indica Less .) terhadap Bakteri Propionibacterium acnes. PHARMACON, 8(2), 209-2 18. https://doi.org/https://doi.org/10.35799/pha.8.2019 .29256 .

Thompson, E.B. (1985). Drug Biosreening. America: Graceway Publishing Company, Inc, Pp, 40, 118

Widyawati, P. S., WIjaya, C. H., Hardjosworo, P. S., \& Sajuthi, D. (2011). Evaluasi Aktivitas Antioksidatif Ekstrak Daun Beluntas (Plucea indica) Berdasarkan Perbedaan Ruas Daun. Jurnal Teknologi Pangan, 5(1), $1-17$. https://core.ac.uk/download/pdf/234615371.pdf.

Zein, U. (2004). Diare Akut Disebabkan Bakteri. E-USU Repository, January 2004, 1-15. https://www.researchgate.net/publication/42321299 _Diare_Akut_Disebabkan_Bakteri. 